\title{
Nutritional, Physiochemical, and Biological Value of Muffins Enriched with Edible Insects Flour
}

\author{
Ewelina Zielińska (D), Urszula Pankiewicz * and Monika Sujka (1)
}

Citation: Zielińska, E.; Pankiewicz, U.; Sujka, M. Nutritional,

Physiochemical, and Biological Value of Muffins Enriched with Edible Insects Flour. Antioxidants 2021, 10, 1122. https://doi.org/10.3390/ antiox10071122

Academic Editor: Serkos A

Haroutounian

Received: 7 June 2021

Accepted: 13 July 2021

Published: 14 July 2021

Publisher's Note: MDPI stays neutral with regard to jurisdictional claims in published maps and institutional affiliations.

Copyright: (C) 2021 by the authors Licensee MDPI, Basel, Switzerland. This article is an open access article distributed under the terms and conditions of the Creative Commons Attribution (CC BY) license (https:/ / creativecommons.org/licenses/by/ $4.0 /)$.
Department of Analysis and Evaluation of Food Quality, University of Life Sciences in Lublin, Skromna Str. 8, 20-704 Lublin, Poland; ewelina.zielinska@up.lublin.pl (E.Z.); monika.sujka@up.lublin.pl (M.S.)

* Correspondence: urszula.pankiewicz@up.lublin.pl

\begin{abstract}
Edible insects are gaining attention as a novel food; however, studies with their use in food are still limited. This study aimed to determine the chemical composition, physical parameters, sensory acceptance, and biological properties of muffins enriched with different levels of cricket (Gryllodes sigillatus) and mealworm (Tenebrio molitor) flours. The approximate composition was analyzed, along with the physical and textural properties, color, and consumer acceptance. Moreover, the antioxidant properties, starch digestibility, and glycemic index were determined in vitro. As we expected, the protein content in muffins supplemented with insect flour increased, while the carbohydrates content decreased. Moreover, the total phenolic content and antioxidant capacity against ABTS. ${ }^{+}$and DPPH. increased correspondingly as the percentage of insect flour in the muffins increased. The estimated glycemic index was lower for the fortified muffins than the control $(p<0.05)$. Additionally, enriched muffins were accepted by consumers, and their taste positively surprised respondents $(p<0.05)$. Therefore, the results obtained are satisfactory as regards the use of insects for the supplementation of traditional products, and further research into the addition of insects to other nutrient matrices is needed. Furthermore, examining the effect of insect addition on in vivo food biological activity is highly desirable.
\end{abstract}

Keywords: edible insects; entomophagy; biological activity; muffins with insects; mealworm; cricket

\section{Introduction}

One of the popular trends in food production concerns food fortification, which is related to the growing interest of consumers in this type of food. Food fortification is performed due to several factors, including improving the nutritional value of food, correcting deficiencies in nutrients or minerals, or enhancing health-promoting properties [1]. As a result, products with high protein, vitamin, amino acids, and mineral contents are gaining popularity [2]. Furthermore, not all food products are equally suitable for supplementation. For food fortification to be successful, supplemented foods should be consumed widely and in adequate quantities. For this reason, bakery products such as biscuits or bread, and also pasta, are very often chosen as a food matrix. This type of food can be fortified by the direct addition of a given ingredient during processing. This type of fortification results not only in an increase in the nutritional value of the product, but also changes its rheological and sensory characteristics [1].

Improving the nutritional quality of these types of foods is often achieved by the addition of selected food groups such as legumes, oilseeds, or herbs [1]. However, the trend in food fortification is changing to the use of unconventional sources of nutrients and bioactive ingredients. This is caused, for example, by the need to transform the food industry, leading to rational food management, the use of new technologies, and alternative raw materials, as well as waste management, with a reduced negative impact on the environment. In this context, the use of edible insects as food ingredients can be a beneficial alternative to enriching conventional foods [3]. Insects are undoubtedly an important source of protein, but also of micronutrients and bioactive compounds [4-6]. 
Insects are a natural source of substances with biological activity, including antibacterial, antiviral, and anti-inflammatory activities [7]. In traditional medicine, some species of edible insects are used to treat inflammatory diseases $[8,9]$. Stull et al. found that eating a breakfast enriched with $25 \mathrm{~g}$ of cricket powder for 2 weeks reduced circulating levels of the pro-inflammatory cytokine TNF- $\alpha$ in the plasma of 20 healthy adults [10]. In turn, in myoblast cell lines, the cricket Brachytrupes orientalis has been shown to reduce intracellular production of reactive oxygen species (ROS), lipid peroxidation, and increase the expression of Nrf2 and glutathione S-transferase proteins, involved in the redox response to stress, after stimulation with high glucose levels [11]. Moreover, hydrolysate and peptide fractions from insects such as Tenebrio molitor, Schistocerca gregaria, and Gryllodes sigillatus exhibited the ability to inhibit enzyme activity, such as lipoxygenase and cyclooxygenase-2, as well as displaying free radical scavenging activity in vitro [12,13]. These insect species also inhibited enzymes involved in the pathogenesis of metabolic syndrome in vitro [14]. However, the major interest is in the antioxidant properties of flours derived from insects $[15,16]$, because antioxidants are among the most studied issues in both food science and nutrition [17]. Di Mattia et al. showed that water-soluble extracts of grasshoppers, silkworm, and crickets display five-fold higher values of antioxidant capacity, measured as TEACaq (mmol TE/100 g), than fresh orange juice [18]. There are many in vivo studies indicating the key role of antioxidant activity in the treatment of many diseases, such as cardiovascular disorders, diabetes, cancer, and neurodegenerative disorders. Furthermore, antibacterial, antiviral, anti-inflammatory, and anticancer activities are often associated with antioxidant properties $[17,19,20]$. It should be noted, however, that most studies focus on in vitro analysis, which can only provide an overview and direction for further research including clinical trials. It should therefore be noted that the results obtained from in vitro tests can only indicate the potential properties of the tested raw materials; nevertheless, they are necessary to carry out as a first step in the overall assessment of the bioactivity of the product.

Furthermore, the use of insects in the food industry has other positive benefits related to food sustainability. Insects have a high dry matter conversion of ingested food, which reduces breeding costs [21,22]. Moreover, insect farming requires less feed and water, with a reduced environmental impact, than conventional protein sources [23,24]. Although food sustainability is becoming increasingly important, consumer acceptance of insect consumption is still limited $[25,26]$. Although entomophagy is common in many countries around the world, mainly in Southeast Asia and South America, there is a significant barrier in terms of attitudes towards the use of insects as food, especially in Western societies, which show low acceptance of entomophagy [27]. The acceptance and popularity of entomophagy vary considerably across countries, as the willingness to consume depends on the cultural region, as confirmed by a survey of German and Chinese consumers. This cross-cultural comparison was made based on consumers' willingness to consume various insect-based products; processed (e.g., cricket flour-based cookies) and unprocessed (e.g., crickets). Chinese consumers rated all insect-based foods more positively in terms of taste, nutritional value, familiarity, and social acceptance, and had a greater willingness to consume tested foods than did German consumers. Moreover, no differences were observed between the ratings of processed and unprocessed foods incorporating insect powders by the Chinese consumers, while German consumers had a greater willingness to eat processed insect-based foods [28]. For the introduction of insects as a food in the West, it is important to design suitable products to gain appropriate consumer acceptance, because the simple addition of insects to known products is not sufficient; monitoring of the physicochemical, as well as sensory characteristics of such products, is required [29].

Recently, there has been a lot of work focusing on designing products with insects and studying their properties. The most commonly fortified products are bakery products $[3,30]$, bread [2,31-33], biscuits [34-36], snacks [37,38], pasta [39], tortillas [40], and meat products such as pâtés [41,42], frankfurters [43], sausages [44], or burgers [45,46]. This research aimed to study the incorporation of flours from two different insects (mealworms Tenebrio 
molitor and crickets Gryllodes sigillatus) into wheat muffins, by assessment of physical parameters, nutrient composition, bioactive properties, and sensory characteristics.

\section{Materials and Methods}

\subsection{Materials}

Wheat flour (type 500) (protein 10\%, fat $1 \%$, carbohydrates $76 \%$ ), milk (protein $3 \%$, fat $3.2 \%$, carbohydrates $4.7 \%$ ), rapeseed oil, eggs (protein $7.3 \%$, fat $5.7 \%$, carbohydrates $0.3 \%$ ), sugar, and baking powder were purchased from a local market. The mealworms Tenebrio molitor (Linnaeus, Coleoptera: Tenebrionidae) (larvae), and crickets Gryllodes sigillatus (Fabricius, Orthoptera: Gryllidae) (adult) were obtained from a local breeder, Bugstore (Krakow, Poland). Insects were fasted for two days to empty their digestive tract and next they were frozen for $48 \mathrm{~h}$ at $-20^{\circ} \mathrm{C}$ and lyophilized. Afterward, the insects were ground in a laboratory grinder (IKA A11 basic), and the obtained flour was passed through a 20 mesh sieve. All the chemicals and reagents used were of analytical grade.

\subsection{Muffin Preparation}

Muffins were prepared in four variants, differing in insect flour addition $(2 \%, 6 \%$, $10 \%(w / w)$ by replacing an equivalent amount of wheat flour) or with the addition of whole insects $(6 \%(w / w)$ of wheat flour) for each of the studied insect species. Control muffins were prepared without the addition of insects. The recipe of the muffins contained ingredients commonly used for their preparation, and these were wheat flour $(43.4 \%)$, milk $(31.2 \%)$, rapeseed oil $(11.6 \%)$, eggs $(8.1 \%)$, sugar $(5.4 \%)$, and baking powder $(0.3 \%)$. Wet and dry ingredients were combined separately and then combined briefly to blend the ingredients. The batter $(60 \mathrm{~g})$ was poured into a muffin cup and baked at $190^{\circ} \mathrm{C}$ for $20 \mathrm{~min}$ in a preheated oven. The biscuits were then allowed to cool at room temperature and subjected to a consumer acceptance analysis, as well as color measurements and texture profile analysis, which were carried out within $24 \mathrm{~h}$ of baking. Until then, the muffins were stored in airtight containers and next were frozen at $-20{ }^{\circ} \mathrm{C}$ so that further analyses could be performed.

\subsection{Nutrient Composition}

The samples of flours and muffins were estimated for their moisture, ash, fat, and protein content by employing the standard methods of analysis [47]. Carbohydrates were determined by difference, by the following formula: 100 - (weight in grams (protein + fat + ash + moisture) in $100 \mathrm{~g}$ ). The conversion method was used for the determination of the nutritional value [48].

\subsection{Color Measurements}

An EnviSense colorimeter NH310 (EnviSense, Lublin, Poland) was used to measure the color of the muffins. Color differences were recorded in the CIE $\mathrm{L}^{*} \mathrm{a}^{*} \mathrm{~b}^{*}$ scale, in terms of lightness $\left(\mathrm{L}^{*}\right)$ and color $\left(\mathrm{a}^{*}\right.$-redness, $\mathrm{b}^{*}$-yellowness). Chroma $\left(\mathrm{C}^{*}\right)$ and hue $\left(\mathrm{h}^{\circ}\right)$ were also recorded. Furthermore, the total color difference $(\Delta \mathrm{E})$ was calculated using the following formula:

$$
\Delta \mathrm{E}=\sqrt{\Delta \mathrm{L}^{* 2}+\Delta \mathrm{a}^{* 2}+\Delta \mathrm{b}^{* 2}},
$$

where $\Delta \mathrm{L}^{*}, \Delta \mathrm{a}^{*}$, and $\Delta \mathrm{b}^{*}$ are differences in the $\mathrm{L}^{*}, \mathrm{a}^{*}, \mathrm{~b}^{*}$ values between the reference sample and the test sample, respectively.

\subsection{Textural Analysis of Muffins}

The texture profile analysis (TPA) of the obtained muffins was performed one day after baking, according to the method described by Mildner-Szkudlarz et al. [49], with a slight modification. A TA.XTplus texture analyzer (Stable Micro System Co. Ltd., Vienna Court, UK) equipped with a $5 \mathrm{~kg}$ load cell and a cylindrical plunger probe of $10-\mathrm{cm}$ diameter was used. The measurement was performed at the pre-test speed: $2.0 \mathrm{~mm} / \mathrm{s}$, and test speed: 
$2.0 \mathrm{~mm} / \mathrm{s}$. The muffins were cut into $25 \mathrm{~mm}$ thick slices (the top and bottom layers were discarded) and they were compressed twice to $50 \%$ of their original height. During the test, hardness, springiness, cohesiveness, chewiness (product of hardness $\times$ cohesiveness $\times$ springiness, $N$ ), and resilience were measured. Texture analysis of muffin samples was carried out in triplicates for each sample.

\subsection{Consumer Acceptance Analysis}

The organoleptic analysis was carried out on freshly baked ( $1 \mathrm{~h}$ after baking) muffins. The evaluation of the muffins was performed by 26 panelists aged from 20 to 29 years, who were randomly selected among the students of the University of Life Sciences in Lublin, Poland. The color, aroma, texture, taste, and overall acceptability of the muffins were assessed on a scale of 1 to 5 (5-excellent, 1-extremely unsatisfactory). The conditions of the evaluation were constant.

\subsection{Consumer Study}

Consumer study was carried out in two parts-before and after the organoleptic evaluation of muffins. The test consisted of a set of statements scored on a 5-point Likert scale ranging from "strongly disagree" to "strongly agree" [50]. This study aimed to record consumers' opinions about the muffins before and after tasting them and to learn about their willingness to further consume insects, considering the perceptions they had in the sensory analysis. The statements assessed before the sensory evaluation of the muffins were as follows:

(1) I am curious about the taste of muffins

(2) All muffin variants look equally appetizing

(3) The addition of insect flour made me reluctant to taste them

(4) The addition of whole insects made me reluctant to taste them

(5) Adding insect flour to muffins is a better idea than adding whole insects

(6) The addition of whole insects to muffins causes more reluctance to taste them than the addition of insect flour.

In turn, after sensory analysis of the muffins, consumers were asked to assess the following items:

(1) The taste of muffins with insect/insect flour surprised me positively

(2) I would like to try other insect products

(3) Muffins with insect flour are acceptable to me, I would eat them in the future

(4) Muffins with whole insects are acceptable to me, I would eat them in the future

(5) I would recommend that others try baked products with insect/insect flour.

\subsection{Antioxidant Properties}

2.8.1. Extraction of Bioactive Compounds

The crushed in mortar muffin samples $(1 \mathrm{~g})$ were shaken with $10 \mathrm{~mL}$ of $4: 1$ ethanol/water $(v / v)$ in a laboratory shaker. After $120 \mathrm{~min}$, the samples were centrifuged at $3000 \times g$ for $10 \mathrm{~min}$. The supernatant was stored at $-20^{\circ} \mathrm{C}$ for further analysis [51].

\subsubsection{DPPH Radical Scavenging Activity}

The Brand-Williams, Cuvelier, and Berset [52] method with slight modification was used to evaluate the $\mathrm{DPPH}^{\bullet}$ scavenging activity. A mixture containing $0.1 \mathrm{~mL}$ volume of the sample and $0.9 \mathrm{~mL}$ of a $6 \mu \mathrm{M}$ solution of $\mathrm{DPPH}^{\bullet}$ in $75 \%$ methanol was prepared. The absorbance of this mixture was read at $515 \mathrm{~nm}$ after $30 \mathrm{~min}$ of the reaction, with $75 \%$ methanol used as a blank. The scavenging effect was calculated using the equation:

$$
\text { Scavenging activity }(\%)=[1-(\text { A sample } / \text { A control })] \times 100,
$$

where A sample is the absorbance of the mixture of sample and $\mathrm{DPPH}^{\bullet}$; $\mathrm{A}$ control is the absorbance of the control (DPPH• solution). 
The results were expressed as Trolox equivalent antioxidant activity (TEAC) values (mM Trolox).

\subsubsection{ABTS Radical Scavenging Activity}

The method of Re et al. [53], with slight modifications, was used to evaluate the $\mathrm{ABTS}^{\bullet+}$ scavenging activity. The radical solution was prepared with ABTS and potassium persulfate, diluted in water at $2.45 \mathrm{mM}$ concentration. The solution was kept in the dark for $16 \mathrm{~h}$ to develop a radical and then was diluted to reach an absorbance value around 0.7 at $734 \mathrm{~nm}$. Then, $0.05 \mathrm{~mL}$ of each sample was added to $2.95 \mathrm{~mL}$ of the ABTS ${ }^{\bullet+}$ solution. After $30 \mathrm{~min}$ of the reaction the absorbance of the mixture was read at $734 \mathrm{~nm}$. Distilled water was used as a blank. The scavenging effect was calculated according to the equation:

$$
\text { Scavenging activity }(\%)=[1-(\text { A sample } / \text { A control })] \times 100,
$$

where A sample is the absorbance of the mixture of sample and $\mathrm{ABTS}^{\bullet+}$; $\mathrm{A}$ control is the absorbance of the control $\left(\mathrm{ABTS}^{\bullet+}\right.$ solution).

The results were expressed as Trolox equivalent antioxidant activity (TEAC) values (mM Trolox).

\subsubsection{Total Phenolic Content}

The TPC of different samples was determined according to the Folin-Ciocalteu spectrophotometric method [54]. Briefly, $0.04 \mathrm{~mL}$ of extracts was diluted with $3.16 \mathrm{~mL}$ of distilled water, and $0.2 \mathrm{~mL}$ of Folin-Ciocalteu's reagent. After vigorous stirring in a vortex mixer, $0.6 \mathrm{~mL}$ of saturated sodium carbonate was added and incubation was carried out at $40{ }^{\circ} \mathrm{C}$ for $30 \mathrm{~min}$. The absorbance was measured at $725 \mathrm{~nm}$. A control solution was prepared accordingly, but without extract addition, replacing it with water. The results were expressed as mg of gallic acid equivalents (GAE) per gram of sample.

\subsection{In Vitro Digestibility of Muffins}

The procedure of Monro et al. [55], with slight modifications, was used to determine in vitro digestibility of the starch. Briefly, $30 \mathrm{~mL}$ of water and $0.8 \mathrm{~mL}$ of $1 \mathrm{M} \mathrm{HCl}$ were added to $1 \mathrm{~g}$ of the sample to reach a $\mathrm{pH}$ of 2.5. To start the gastric digestion, $1 \mathrm{~mL}$ of $10 \%$ pepsin solution in $0.05 \mathrm{M} \mathrm{HCl}$ was added and samples were incubated for $30 \mathrm{~min}$ at $37^{\circ} \mathrm{C}$ with stirring $(130 \mathrm{rpm})$. In the next step, the small intestine phase was started by the addition of $2 \mathrm{~mL}$ of $1 \mathrm{M} \mathrm{NaHCO}_{3}$ and $5 \mathrm{~mL}$ of $0.1 \mathrm{M}$ phosphate buffer (pH 6), and next $4.6 \mathrm{mg}$ amyloglucosidase and $5 \mathrm{~mL}$ of $2.5 \%$ pancreatin in $0.1 \mathrm{M}$ phosphate buffer ( $\mathrm{pH} 6)$. The volume of hydrolysates was made up with distilled water to $55 \mathrm{~mL}$. Digesta aliquots of $1.0 \mathrm{~mL}$ were removed at 20,30,60,90, 120, and $180 \mathrm{~min}$ from the start of amylolysis, and then added to $4 \mathrm{~mL}$ absolute ethanol in a tube and mixed to inactivate the enzymes.

\subsection{Rapidly and Slowly Digested Starch Contents}

The procedure of Soong, Tan, Leong, and Henry [56] was used to measure the reducing sugars released during in vitro digestion of the muffins, and on this basis the rapidly digestible starch (RDS) and slowly digestible starch (SDS) levels were evaluated. A dinitrosalicylic acid (DNS) colorimetric method was used to determine sugars as monosaccharides released during in vitro digestion. Briefly, $50 \mathrm{~mL}$ of supernatant was added to $0.25 \mathrm{~mL}$ of acetate buffer containing $0.4 \%$ invertase and $1 \%$ amyloglucosidase and incubated at room temperature for $30 \mathrm{~min}$ to complete the depolymerization into monosaccharides. Next, $0.75 \mathrm{~mL}$ of DNS mixture $(0.5 \mathrm{mg} / \mathrm{mL}$ glucose, $4 \mathrm{M} \mathrm{NaOH}$, and DNS reagent at a 1:1:5 ratio) was added and heated for $15 \mathrm{~min}$ at $95-100{ }^{\circ} \mathrm{C}$. After cooling, samples were diluted with $4 \mathrm{~mL}$ distilled water and the absorbance was read at $530 \mathrm{~nm}$ against the blank.

The amount of sugars released was presented as the $\mathrm{mg}$ of glucose/g of each sample and $\mathrm{mg}$ of glucose/g dry weight of the sample. The amount of rapidly digestible starch (RDS) was assessed as the amount of reducing sugars determined in the sample after 20 min from the start of intestinal digestion, whereas the amount of slowly digestible starch 
(SDS) was calculated as the difference between the amount of reducing sugars measured after 120 min of intestinal digestion and RDS content.

\subsection{Glycemic Index In Vitro}

The method of Reis and Abu-Ghannam [57] was adapted to evaluate the in vitro glycemic index (GI) of the muffins. The digestion procedure described above was used in this procedure. Digesta aliquots of $1 \mathrm{~mL}$ were taken at 20,30,60, 90,120, and $180 \mathrm{~min}$ after the start of intestinal digestion in the tubes, with $4 \mathrm{~mL}$ of absolute ethanol used to deactivate the enzymes. The GOPOD method was used for determination of the glucose content in the samples (mg glucose/g sample). Glucose content was plotted as a function of time, and the areas under the hydrolysis curves (AUC) were calculated. The ratio between the AUC of the sample and the AUC for the reference food (white bread) was used to calculate the hydrolysis index (HI) values expressed as percentages, which were normalized for the total carbohydrate available in each sample and reference. The glycemic index was predicted according to the equation defined by Goñi, Garcia-Alonso, and Saura-Calixto [58]:

$$
\mathrm{GI}(\%)=39.71+0.549 \times \mathrm{HI},
$$

\subsection{Statistical Analysis}

All assays were performed in triplicate and the obtained data are presented as means \pm SEM (the standard error of the mean). Statistical analyses were carried out using Statistica (version 13.0, StatSoft, Krakow, Poland) for comparison of means using ANOVA with post hoc Tukey's honestly significant difference (HSD) test at the significance level $p<0.05$. A one-way ANOVA test was used in the questionnaire analysis as well. The insect flour addition and TPC were compared with the values obtained for antioxidant capacity (ABTS and DPPH) using Pearson's correlation test.

\section{Results and Discussion}

\subsection{Nutrient Composition}

Edible insects are known as a valuable source of protein, and the protein contents for the studied insects flours were determined as $54.29 \%$ for mealworm and $71.15 \%$ for cricket (Table 1). Therefore, the supplementation of muffins with insect flour resulted in the expected proportional increase in the protein content of muffins as the addition of flour increased. The protein content increased by $1.3 \%, 17.1 \%$, and $21.8 \%$ for muffins supplemented with $2 \%, 6 \%$, and $10 \%$ of mealworm flour, respectively, and $16.3 \%$ and $34 \%$ for muffins supplemented with $6 \%$ and $10 \%$ of cricket flour, respectively, compared to reference muffin, in fresh muffin weight. However, considering the difference in muffin moisture, an increase in protein content occurred in all supplemented muffins, successively by $7.8 \%, 18.7 \%$ and $29.1 \%$ for muffins supplemented with $2 \%, 6 \%$, and $10 \%$ of mealworm flour, respectively, and $8.3 \%, 20 \%$, and $37.4 \%$ for muffins supplemented with $6 \%$ and $10 \%$ of cricket flour, respectively, compared to the reference muffin. The higher protein content of cricket flour resulted in a higher increase in protein content in muffins supplemented with it compared to mealworm flour. Moreover, an increase in the protein content of the muffins resulted in a decrease in the carbohydrate content $(p<0.05)$. The fat content of the tested flours was significantly different; $28.01 \%$ in mealworm flour and $14.92 \%$ in cricket flour, which is reflected in the fat content of the supplemented muffins. The studied muffins, except for samples with $2 \%$ insect flour added, had a statistically significantly higher fat content $(p<0.05)$ compared to the control, which was a consequence of the higher fat content of the insects flours than wheat flour. However, these differences were not large because the main source of fat in muffins is the oil added according to the recipe. In turn, the differences in energy value were mainly due to the different moisture contents of the muffins. All supplemented muffins had a higher moisture content than the control, which may have been due to the addition of an ingredient with a higher water absorption capacity, which influenced the properties of the bread [59]. Differences in the moisture content of 
muffins can also be related to the muffin baking process. Therefore, to eliminate the effect of moisture on the content of essential nutrients in the muffins, their content as \% of dry weight is presented in Table 1.

Table 1. Nutritional value of muffins.

\begin{tabular}{|c|c|c|c|c|c|c|c|}
\hline $\begin{array}{l}\text { Insect } \\
\text { Species }\end{array}$ & $\begin{array}{l}\text { Insect Flour } \\
\text { Substitution }\end{array}$ & Protein (\%) & Fat $(\%)$ & Ash (\%) & $\begin{array}{c}\text { Carbohydrates } \\
(\%)\end{array}$ & Moisture (\%) & $\begin{array}{l}\text { Energy Value } \\
(\mathrm{kJ} / 100 \mathrm{~g})\end{array}$ \\
\hline Control & - & $7.8 \pm 0.55^{b c}$ & $15.32 \pm 0.19^{c}$ & $0.9 \pm 0.05^{b}$ & $51.17 \pm 0.85^{\mathrm{a}}$ & $24.81 \pm 0.89^{\mathrm{d}}$ & $1569 \pm 8.0^{a}$ \\
\hline \multirow{5}{*}{$\begin{array}{l}\text { Mealworm } \\
\text { (Tenebrio } \\
\text { molitor) }\end{array}$} & $2 \%$ & $7.9 \pm 0.55^{b c}$ & $14.14 \pm 0.38^{\mathrm{de}}$ & $0.88 \pm 0.07^{b}$ & $47.75 \pm 0.67^{b}$ & $29.33 \pm 0.03^{b}$ & $1469 \pm 11.2^{\mathrm{e}}$ \\
\hline & $6 \%$ & $9.13 \pm 0.64^{a b c}$ & $16.68 \pm 0.13^{\mathrm{a}}$ & $0.95 \pm 0.05^{b}$ & $47.43 \pm 0.55^{b c}$ & $25.86 \pm 0.59 \mathrm{~cd}$ & $1579 \pm 13.52^{a}$ \\
\hline & $10 \%$ & $9.5 \pm 0.66^{\mathrm{ab}}$ & $16.39 \pm 0.1^{\mathrm{ab}}$ & $0.98 \pm 0.05^{b}$ & $44.0 \pm 0.42^{\mathrm{d}}$ & $29.13 \pm 0.8^{b}$ & $1516 \pm 10.2^{\mathrm{cd}}$ \\
\hline & whole insects $6 \%$ & $8.63 \pm 0.6^{b c}$ & $15.51 \pm 0.41^{b c}$ & $0.95 \pm 0.05^{b}$ & $45.28 \pm 0.64^{\mathrm{de}}$ & $29.63 \pm 0.89^{b}$ & $1490 \pm 13.5^{\text {de }}$ \\
\hline & pure insect flour & $54.29 \pm 1.2$ & $28.01 \pm 0.18$ & $1.39 \pm 0.05$ & $11.59 \pm 0.05$ & $4.72 \pm 0.08$ & $2157 \pm 13.7$ \\
\hline \multirow{5}{*}{$\begin{array}{c}\text { Cricket } \\
\text { (Gryllodes } \\
\text { sigillatus) }\end{array}$} & $2 \%$ & $7.63 \pm 0.53^{c}$ & $13.55 \pm 0.52^{\mathrm{e}}$ & $0.82 \pm 0.08^{b}$ & $45.96 \pm 0.72^{\mathrm{cd}}$ & $32.04 \pm 1.07^{\mathrm{a}}$ & $1412 \pm 12.22^{\mathrm{f}}$ \\
\hline & $6 \%$ & $9.07 \pm 0.64^{\mathrm{abc}}$ & $15.17 \pm 0.17^{c}$ & $0.93 \pm 0.06^{b}$ & $47.74 \pm 0.23^{b}$ & $27.09 \pm 0.26^{c}$ & $1527 \pm 15.56^{b c}$ \\
\hline & $10 \%$ & $10.45 \pm 0.73^{\mathrm{a}}$ & $16.42 \pm 0.48^{a b}$ & $1.0 \pm 0.09^{b}$ & $45.47 \pm 0.58^{\mathrm{de}}$ & $26.66 \pm 0.46^{c}$ & $1558 \pm 13.74 .^{\mathrm{ab}}$ \\
\hline & whole insects $6 \%$ & $9.3 \pm 0.65^{a b c}$ & $14.82 \pm 0.29^{\mathrm{cd}}$ & $0.95 \pm 0.06^{b}$ & $47.68 \pm 0.34^{b}$ & $27.25 \pm 0.8^{c}$ & $1517 \pm 11.6^{\mathrm{cd}}$ \\
\hline & pure insect flour & $71.15 \pm 1.1$ & $14.92 \pm 0.08$ & $4.35 \pm 0.08$ & $4.83 \pm 0.02$ & $4.75 \pm 0.09$ & $1844 \pm 10.3$ \\
\hline \multicolumn{8}{|c|}{$\%$ of dry weight } \\
\hline & & Protein & Fat & Ash & Carbohydrates & & \\
\hline Control & - & $10.37 \pm 0.73^{c}$ & $20.38 \pm 0.25^{c}$ & $1.19 \pm 0.05^{b}$ & $68.06 \pm 1.13^{a}$ & & \\
\hline \multirow{4}{*}{$\begin{array}{c}\text { Mealworm } \\
\text { (Tenebrio } \\
\text { molitor) }\end{array}$} & $2 \%$ & $11.18 \pm 0.77^{b c}$ & $20.01 \pm 0.54^{c}$ & $1.24 \pm 0.07^{b}$ & $67.57 \pm 0.95^{a b}$ & & \\
\hline & $6 \%$ & $12.31 \pm 0.85^{\mathrm{abc}}$ & $22.49 \pm 0.18^{\mathrm{a}}$ & $1.28 \pm 0.05^{b}$ & $63.92 \pm 0.74$ cde & & \\
\hline & $10 \%$ & $13.39 \pm 0.91 \mathrm{ab}$ & $23.13 \pm 0.14^{\mathrm{a}}$ & $1.38 \pm 0.05^{b}$ & $62.1 \pm 0.59 \mathrm{de}$ & & \\
\hline & whole insects $6 \%$ & $12.27 \pm 0.84^{\mathrm{abc}}$ & $22.04 \pm 0.58^{a b}$ & $1.35 \pm 0.05^{b}$ & $64.34 \pm 0.91^{\mathrm{cd}}$ & & \\
\hline \multirow{4}{*}{$\begin{array}{c}\text { Cricket } \\
\text { (Gryllodes } \\
\text { sigillatus) }\end{array}$} & $2 \%$ & $11.23 \pm 0.77^{b c}$ & $19.93 \pm 0.75^{c}$ & $1.21 \pm 0.08^{b}$ & $67.63 \pm 1.06^{\mathrm{ab}}$ & & \\
\hline & $6 \%$ & $12.44 \pm 0.86^{\mathrm{abc}}$ & $20.81 \pm 0.23^{b c}$ & $1.28 \pm 0.06^{\mathrm{b}}$ & $65.47 \pm 0.32 \mathrm{bc}$ & & \\
\hline & $10 \%$ & $14.25 \pm 0.98^{\mathrm{a}}$ & $22.39 \pm 0.65^{\mathrm{a}}$ & $1.36 \pm 0.09^{b}$ & $62.0 \pm 0.8^{\mathrm{e}}$ & & \\
\hline & whole insects $6 \%$ & $12.79 \pm 0.87^{a b c}$ & $20.36 \pm 0.4^{c}$ & $1.30 \pm 0.06^{b}$ & $65.55 \pm 0.47^{b c}$ & & \\
\hline
\end{tabular}

Values with different letters in the same column indicate significant differences $(p<0.05)$.

\subsection{Color Measurements}

The results of the crumb color measurements of the muffins containing insect flours showed different brownish intensities (Table 2). Increasing the amount of insect flour decreased the lightness $\left(\mathrm{L}^{*}\right)$ (except for samples with $2 \%$ flour addition, as also noted by other authors for muffins enriched with cricket flour [60]), redness ( $\left.a^{*}\right)$ for muffins fortified with $2 \%$ of insects' flour and whole insects, and the yellowness $\left(b^{*}\right)$ of all samples, while increasing total color difference $(\Delta \mathrm{E})$. Color is an important feature for baked products, because it is one of several factors influencing consumer acceptance [3]. Changing the color of bakery products to a darker color does not necessarily mean a lower consumer evaluation. Other authors suggested the similarity of these products to the color of whole grain products [60]. The color of the supplemented muffins was darker than the control, similarly to products enriched with insect flour a noted by other authors $[3,33,35,39,60]$. In turn, the dark color of fortified products may depend on several factors, such as the color of the raw materials; insect flour is darker than wheat flour. González et al. (2019) noted that the addition of Hermetia illucens flour caused a stronger darkening of the bread than the addition of mealworm T. molitor or cricket $A$. domestica flour. However, the addition of all flours caused browning of the crumb in a similar way to lentils and chickpea flours that resemble in color insect flours. Furthermore, the color changes which were observed could have been the result of the conversion of the nutrients present in the muffins, e.g., proteins from insects, through the heat treatment applied. Samples with more insect flour contained a higher amount of protein, which could intensify Maillard reactions [61]. Moreover, the fortified muffins had less saturated colors than the control (lower $C^{*}$ values). This means that the shade of the color changed from yellowish to redder. 
Table 2. Color determinants of muffins.

\begin{tabular}{|c|c|c|c|c|c|c|c|}
\hline $\begin{array}{l}\text { Insect Added } \\
\text { to Muffin }\end{array}$ & $\begin{array}{l}\text { Insect Flour } \\
\text { Substitution }\end{array}$ & $\mathbf{L}^{*}$ & $a^{*}$ & $\mathbf{b}^{*}$ & $C^{*}$ & $\mathbf{h}^{\circ}$ & $\Delta \mathrm{E}$ \\
\hline Control & - & $62.9 \pm 0.61^{b}$ & $2.30 \pm 0.15^{a}$ & $21.47 \pm 0.45^{\mathrm{a}}$ & $21.59 \pm 0.46^{\mathrm{a}}$ & $83.88 \pm 0.35^{b}$ & - \\
\hline \multirow{4}{*}{$\begin{array}{c}\text { Mealworm } \\
\text { (Tenebrio } \\
\text { molitor) }\end{array}$} & $2 \%$ & $66.42 \pm 0.46^{\mathrm{a}}$ & $1.49 \pm 0.15^{c}$ & $18.05 \pm 0.49^{c}$ & $18.11 \pm 0.49^{c}$ & $85.29 \pm 0.36^{b}$ & $4.98^{g}$ \\
\hline & $6 \%$ & $52.65 \pm 1.41^{\mathrm{d}}$ & $2.22 \pm 0.09^{a}$ & $16.06 \pm 0.55^{\mathrm{e}}$ & $16.41 \pm 0.56^{\mathrm{f}}$ & $78.10 \pm 0.08^{d}$ & $11.63^{c}$ \\
\hline & $10 \%$ & $46.12 \pm 0.45^{\mathrm{e}}$ & $3.38 \pm 0.09^{a}$ & $13.62 \pm 0.14^{\mathrm{f}}$ & $13.80 \pm 0.15^{g}$ & $80.74 \pm 0.3^{\mathrm{cd}}$ & $18.52^{\mathrm{a}}$ \\
\hline & $6 \%$ of whole insects & $54.99 \pm 0.9^{\mathrm{d}}$ & $0.73 \pm 0.07^{\mathrm{d}}$ & $18.15 \pm 1.26^{c}$ & $17.49 \pm 0.62^{\mathrm{d}}$ & $88.41 \pm 0.66^{a}$ & $8.76^{\mathrm{e}}$ \\
\hline \multirow{4}{*}{$\begin{array}{c}\text { Cricket } \\
\text { (Gryllodes } \\
\text { Sigillatus) }\end{array}$} & $2 \%$ & $63.58 \pm 0.94^{a b}$ & $2.02 \pm 0.19^{a}$ & $16.67 \pm 0.62^{d}$ & $16.80 \pm 0.63^{\mathrm{e}}$ & $83.12 \pm 0.44^{b c}$ & $4.85^{g}$ \\
\hline & $6 \%$ & $59.26 \pm 0.43^{c}$ & $3.51 \pm 0.17^{\mathrm{a}}$ & $13.16 \pm 0.54^{g}$ & $13.62 \pm 0.56^{g}$ & $75.08 \pm 0.36^{\mathrm{e}}$ & $9.15^{\mathrm{d}}$ \\
\hline & $10 \%$ & $54.76 \pm 0.56^{\mathrm{d}}$ & $3.62 \pm 0.16^{a}$ & $12.63 \pm 0.23^{h}$ & $13.14 \pm 0.24^{h}$ & $74.02 \pm 0.6^{\mathrm{e}}$ & $12.09^{b}$ \\
\hline & $6 \%$ of whole insects & $54.63 \pm 1.32^{d}$ & $1.49 \pm 0.08^{c}$ & $20.1 \pm 0.05^{b}$ & $20.16 \pm 0.05^{b}$ & $85.75 \pm 0.23^{a b}$ & $8.42^{\mathrm{f}}$ \\
\hline
\end{tabular}

Values followed by a similar superscript in a column do not differ significantly $(p<0.05)$. Lightness $\left(\mathrm{L}^{*}\right)$ and color (a*-redness, $\mathrm{b}^{*}-$ yellowness). Chroma $\left(\mathrm{C}^{*}\right)$ and hue $\left(\mathrm{h}^{\circ}\right)$.

The total color difference $(\Delta \mathrm{E})$ between the control muffin and the supplemented muffins was significant because color differences $>3$ are obvious to the human eye [62]. A higher difference was noted for mealworm flour addition, ranging from 4.98 to 18.52, with a total color difference for muffins with cricket flour addition of 4.85-12.09.

\subsection{Textural Analysis of Muffins}

The texture parameters, including hardness, springiness, cohesiveness, chewiness, and resilience of the studied muffins, are presented in Table 3. The supplementation of muffins with insect flour in our experiment gave the muffins a softer texture compared to the control, as evidenced by the significant $(p<0.05)$ decrease in hardness, springiness, resilience, cohesiveness, and chewiness of the muffins. Generally, muffins enriched with insect flour showed a reduction of textural parameters values, with a few exceptions; the hardness and chewiness for muffins with the addition of $10 \%$ cricket flour remained constant $(p<0.05)$, and the cohesiveness for muffins with the addition of $6 \%$ and $10 \%$ cricket flour increased slightly in comparison to the control muffin. This indicates that the addition of cricket flour has a more significant effect on the texture of muffins than mealworm flour.

Table 3. Textural properties of muffins.

\begin{tabular}{|c|c|c|c|c|c|c|}
\hline $\begin{array}{l}\text { Insect Added } \\
\text { to Muffin }\end{array}$ & $\begin{array}{l}\text { Insect Flour } \\
\text { Substitution }\end{array}$ & Hardness (N) & Springiness (\%) & Cohesiveness & Chewiness (N) & Resilience \\
\hline Control & - & $121.4 \pm 9.0^{\mathrm{a}}$ & $0.84 \pm 0.01^{\mathrm{a}}$ & $0.42 \pm 0.02^{a b c}$ & $42.66 \pm 4.5^{\mathrm{a}}$ & $0.19 \pm 0.01^{\mathrm{a}}$ \\
\hline \multirow{4}{*}{$\begin{array}{c}\text { Mealworm } \\
\text { (Tenebrio } \\
\text { molitor) }\end{array}$} & $2 \%$ & $91.2 \pm 7.37^{b c}$ & $0.77 \pm 0.02^{b}$ & $0.40 \pm 0.04^{c}$ & $27.76 \pm 2.0^{\mathrm{cd}}$ & $0.15 \pm 0.01 \mathrm{cde}$ \\
\hline & $6 \%$ & $102.9 \pm 5.5^{\mathrm{ab}}$ & $0.76 \pm 0.01^{b}$ & $0.37 \pm 0.01^{c}$ & $29.06 \pm 1.6^{\mathrm{cd}}$ & $0.14 \pm 0.01^{\mathrm{de}}$ \\
\hline & $10 \%$ & $107.5 \pm 9.3^{a b}$ & $0.76 \pm 0.02^{b}$ & $0.44 \pm 0.03^{a b c}$ & $36.21 \pm 2.9^{a b c}$ & $0.17 \pm 0.01 \mathrm{abc}$ \\
\hline & $6 \%$ of whole insects & $124.2 \pm 9.82^{\mathrm{a}}$ & $0.77 \pm 0.04^{b}$ & $0.41 \pm 0.04^{b c}$ & $38.84 \pm 0.77^{a b}$ & $0.18 \pm 0.01^{\mathrm{ab}}$ \\
\hline \multirow{4}{*}{$\begin{array}{c}\text { Cricket } \\
\text { (Gryllodes } \\
\text { sigillatus) }\end{array}$} & $2 \%$ & $98.3 \pm 15.0^{\mathrm{ab}}$ & $0.75 \pm 0.01^{b}$ & $0.40 \pm 0.01^{c}$ & $29.90 \pm 4.6^{\mathrm{bcd}}$ & $0.13 \pm 0.01^{\mathrm{e}}$ \\
\hline & $6 \%$ & $67.7 \pm 8.6^{c}$ & $0.75 \pm 0.02^{b}$ & $0.48 \pm 0.03^{a b}$ & $24.55 \pm 3.5^{\mathrm{d}}$ & $0.15 \pm 0.01^{\mathrm{cde}}$ \\
\hline & $10 \%$ & $121.4 \pm 12.7^{\mathrm{a}}$ & $0.74 \pm 0.01^{b}$ & $0.49 \pm 0.01^{\mathrm{a}}$ & $44.40 \pm 4.8^{\mathrm{a}}$ & $0.16 \pm 0.01 \mathrm{bcc}$ \\
\hline & $6 \%$ of whole insects & $92.3 \pm 10.3^{b c}$ & $0.77 \pm 0.03^{b}$ & $0.38 \pm 0.2^{c}$ & $26.46 \pm 2.7^{\mathrm{d}}$ & $0.16 \pm 0.01 \mathrm{bcc}$ \\
\hline
\end{tabular}

Values different letters in the same column indicate significant differences $(p<0.05)$.

The springiness value reflects the muffin's ability to return to its original shape when the deforming force is removed, and this is associated with the freshness of a product, with a high-quality muffin having a higher springiness value. The control muffin was significantly $(p<0.05)$ springier $(0.84 \%)$ than the fortified muffins for which the springiness decreased to the same extent $(0.74-0.77 \%)$. Moisture content can also affect springiness; the supplemented muffins were characterized by a higher moisture than the control. Less springiness indicates a tendency to crumble. Moreover, a lower springiness and cohesiveness indicate a lower specific volume and less aerated structure in muffins [63]. This is an unfavorable change in terms of consumer acceptance. In turn, a lower chewiness 
indicates that it requires less time to chew a piece of the muffin before swallowing [3]. Consumers may feel difficulty during consuming muffins with very high chewiness, so this is a useful change. Moreover, reducing the hardness of muffins is another advantage that has a positive impact on consumer acceptance of the product. Other muffins fortified with millet, flaxseed, or fenugreek seed husk yielded similar results with a decrease in textural parameter values [64-66]. This is due to differences in the baking characteristics of wheat flour and the other flours used for enrichment muffins, as well as different macronutrient contents. It is also worth emphasizing the different moisture content of the selected muffins (Table 1). Although some studies suggest that a difference in moisture content of bakery goods (e.g., bread) of about $5 \%$ does not significantly affect the texture parameters [67], this factor should not be completely excluded as a significant variable affecting the texture of the tested product. Special steps should be taken when processing the dough to ensure that all muffins have the same moisture content, in commercial practice especially; and then the obtained texture parameters might be used to describe a scientific principle. Our study should be considered preliminary, and further research is needed to explain in-depth the effect of insect flour addition on the textural parameters of baked goods.

\subsection{Consumer Acceptance Analysis and Consumer Study}

The organoleptic analysis of muffins on a 5-point scale was carried out among students of the University of Life Sciences in Lublin, and the results are presented in Table 4. Generally, the control muffin received the highest scores for individual characteristics (color-4.38, consistency-4.23, smell—4.31, and taste-4.15), as well as for overall acceptability (4.38), and an increase in the contribution of insect flour in muffins resulted in a proportionally slight decrease in scores. However, it is important to emphasize that a statistical analysis of the results did not show significant differences at a 0.05 significance level. This allows the conclusion that the tested percentage additions of insect flour achieved organoleptic acceptance among the consumers.

Table 4. Consumer acceptance analysis of muffins.

\begin{tabular}{ccccccc}
\hline $\begin{array}{c}\text { Insect Added } \\
\text { to Muffin }\end{array}$ & $\begin{array}{c}\text { Insect Flour } \\
\text { Substitution }\end{array}$ & Color & Consistency & Smell & Taste & $\begin{array}{c}\text { Overall } \\
\text { Acceptability }\end{array}$ \\
\hline Control & - & $4.38 \pm 0.9^{\mathrm{a}}$ & $4.23 \pm 0.7^{\mathrm{a}}$ & $4.31 \pm 0.8^{\mathrm{a}}$ & $4.15 \pm 0.9^{\mathrm{a}}$ & $4.38 \pm 0.6^{\mathrm{a}}$ \\
\hline Mealworm & $2 \%$ & $4.27 \pm 0.7^{\mathrm{a}}$ & $4.15 \pm 0.8^{\mathrm{a}}$ & $4.04 \pm 1.0^{\mathrm{a}}$ & $3.65 \pm 1.0^{\mathrm{a}}$ & $4.00 \pm 0.9^{\mathrm{a}}$ \\
(Tenebrio & $6 \%$ & $3.54 \pm 0.9^{\mathrm{a}}$ & $3.85 \pm 0.8^{\mathrm{a}}$ & $4.15 \pm 1.0^{\mathrm{a}}$ & $4.00 \pm 1.0^{\mathrm{a}}$ & $4.00 \pm 0.9^{\mathrm{a}}$ \\
molitor) & $10 \%$ & $3.15 \pm 0.8^{\mathrm{a}}$ & $3.27 \pm 0.8^{\mathrm{a}}$ & $3.54 \pm 1.0^{\mathrm{a}}$ & $3.31 \pm 1.0^{\mathrm{a}}$ & $3.50 \pm 0.8^{\mathrm{a}}$ \\
& $6 \%$ of whole insects & $3.69 \pm 1.0^{\mathrm{a}}$ & $3.23 \pm 1.0^{\mathrm{a}}$ & $3.65 \pm 0.9^{\mathrm{a}}$ & $2.77 \pm 1.0^{\mathrm{a}}$ & $3.12 \pm 1.0^{\mathrm{a}}$ \\
\hline Cricket & $2 \%$ & $3.73 \pm 0.6^{\mathrm{a}}$ & $3.77 \pm 0.8^{\mathrm{a}}$ & $3.81 \pm 1.0^{\mathrm{a}}$ & $3.73 \pm 0.6^{\mathrm{a}}$ & $3.77 \pm 0.7^{\mathrm{a}}$ \\
(Gryllodes & $6 \%$ & $3.77 \pm 1.0^{\mathrm{a}}$ & $3.73 \pm 1.0^{\mathrm{a}}$ & $3.88 \pm 1.0^{\mathrm{a}}$ & $3.58 \pm 1.0^{\mathrm{a}}$ & $3.88 \pm 1.0^{\mathrm{a}}$ \\
sigillatus) & $10 \%$ & $3.04 \pm 1.0^{\mathrm{a}}$ & $3.42 \pm 0.9^{\mathrm{a}}$ & $3.77 \pm 0.9^{\mathrm{a}}$ & $3.15 \pm 1.0^{\mathrm{a}}$ & $3.58 \pm 0.8^{\mathrm{a}}$ \\
& $6 \%$ of whole insects & $3.58 \pm 0.8^{\mathrm{a}}$ & $3.50 \pm 1.0^{\mathrm{a}}$ & $3.73 \pm 1.0^{\mathrm{a}}$ & $3.19 \pm 1.0^{\mathrm{a}}$ & $3.23 \pm 0.9^{\mathrm{a}}$ \\
\hline
\end{tabular}

Values with different letters in the same column indicate significant differences $(p<0.05)$.

In addition to the organoleptic evaluation, a survey of consumer opinions about the insects was conducted. The test consisted of a set of statements scored on a 5-point Likert scale ranging from "strongly disagree" to "strongly agree". The consumer study was carried out in two parts; before and after the organoleptic evaluation of muffins to contrast the opinions. Generally, consumers were curious about the taste of muffins (3.77) (Table 5). However, the addition of whole insects to the muffins made consumers more reluctant to taste them than the addition of insect flour (4.62). Moreover, females supported this statement more strongly $(4.82)$ than males $(3.50)(p<0.05)$. These results correspond well with our previous studies, where the desire to eat insects was expressed to a greater extent by the males $(52.48 \%)$ than by the females $(35.25 \%)$, as well as those obtained for German consumers by Orsi et al. [68]. De Boer et al. [69] considered that males are more inclined to take on challenges than females, which may have affected this result. 
Table 5. Results of statements before the sensory evaluation of the muffins ( $1=$ strongly disagree; $5=$ strongly agree $)$ on the total sample and by gender.

\begin{tabular}{|c|c|c|c|c|c|c|c|c|}
\hline Statement & Mean (sd) & DF & $t$-Value & $p$-Value & $\begin{array}{c}\text { Male } \\
\text { Mean (sd) }\end{array}$ & $\begin{array}{c}\text { Female } \\
\text { Mean (sd) }\end{array}$ & F-Value & $p$ \\
\hline I am curious about the taste of muffins & $3.77(1.39)$ & 1 & -0.353 & 0.726 & $4.00(0.71)$ & $3.72(0.30)$ & 0.125 & 0.726 \\
\hline All muffin variants look equally appetizing & $2.58(1.24)$ & 1 & 0.566 & 0.566 & $2.25(0.63)$ & $2.64(0.27)$ & 0.320 & 0.577 \\
\hline $\begin{array}{l}\text { The addition of insect flour made me } \\
\text { reluctant to taste them }\end{array}$ & $2.77(1.14)$ & 1 & 1.500 & 0.147 & $2.00(0.56)$ & $2.91(0.24)$ & 2.251 & 0.147 \\
\hline $\begin{array}{l}\text { The addition of whole insects made me } \\
\text { reluctant to taste them }\end{array}$ & $4.38(1.13)$ & 1 & 1.688 & 0.104 & $3.50(0.54)$ & $4.50(0.23)$ & 2.850 & 0.104 \\
\hline $\begin{array}{l}\text { Adding insect flour to muffins is a better } \\
\text { idea than adding whole insects }\end{array}$ & $4.38(0.85)$ & 1 & 1.677 & 0.107 & $3.75(0.41)$ & $4.50(0.18)$ & 2.812 & 0.107 \\
\hline $\begin{array}{l}\text { The addition of whole insects to muffins } \\
\text { causes more reluctance to taste them than } \\
\text { the addition of insect flour }\end{array}$ & $4.62(0.90)$ & 1 & 3.144 & 0.004 & $3.50(0.39)$ & $4.82(0.16)$ & 9.889 & $0.004 *$ \\
\hline
\end{tabular}

DF-Degree of Freedom; Signif. codes: ${ }^{*} p<0.05$, Tukey test.

After the organoleptic evaluation of the muffins, the consumers were positively surprised about the taste of the muffins (3.84) (Table 6). Moreover, the more skeptical females were more surprised (4.04) than males $(2.75)(p<0.05)$. Muffins with insect flour were more acceptable (3.73) than those with whole insects (2.00). In addition, males were more open about these issues than females, as well as about the possibility of tasting other products with insects or recommending them to others. The results of the study confirm that neophobia is an important factor when proposing new products with insects. Similar observations were noted by Barton et al. (2020) [70], that if consumers have a positive experience with entomophagy, they are more willing to try insects in the future. Additionally, by integrating the crickets into a familiar product, the participants' disgust decreased, so processing insects is a way to enhance their acceptance by consumers.

Table 6. Results of statements after the sensory evaluation of the muffins $(1=$ strongly disagree; $5=$ strongly agree) on the total sample and by gender.

\begin{tabular}{|c|c|c|c|c|c|c|c|c|}
\hline Statement & Mean (sd) & DF & $t$-Value & $p$-Value & $\begin{array}{c}\text { Male } \\
\text { Mean (sd) }\end{array}$ & $\begin{array}{c}\text { Female } \\
\text { Mean (sd) }\end{array}$ & F-Value & $p$ \\
\hline $\begin{array}{l}\text { The taste of muffins with insect/insect flour } \\
\text { surprised me positively }\end{array}$ & $3.84(0.88)$ & 1 & 3.154 & 0.004 & $2.75(0.96)$ & $4.04(0.72)$ & 9.947 & 0.004 * \\
\hline I would like to try other insect products & $3.23(1.30)$ & 1 & -1.298 & 0.206 & $4.00(1.41)$ & $3.09(1.27)$ & 1.686 & 0.206 \\
\hline $\begin{array}{l}\text { Muffins with insect flour are acceptable to } \\
\text { me, I would eat them in the future }\end{array}$ & $3.73(1.25)$ & 1 & -1.359 & 0.187 & $4.50(0.58)$ & $3.59(1.31)$ & 1.848 & 0.187 \\
\hline $\begin{array}{l}\text { Muffins with whole insects are acceptable to } \\
\text { me, I would eat them in the future }\end{array}$ & $2.00(1.23)$ & 1 & -1.344 & 0.192 & $2.75(1.71)$ & $1.86(1.13)$ & 1.806 & 0.192 \\
\hline $\begin{array}{l}\text { I would recommend that others try baked } \\
\text { products with insect/insect flour }\end{array}$ & $3.42(1.17)$ & 1 & -1.073 & 0.294 & $4.00(0.81)$ & $3.32(1.21)$ & 1.152 & 0.294 \\
\hline
\end{tabular}

DF-Degree of Freedom; Signif. codes: ${ }^{*} p<0.05$, Tukey test.

\subsection{Antioxidant Properties}

The antioxidant properties of muffins and insect flours were evaluated based on the determination of total phenolic content (TPC) and the ability to neutralize DPPH. and ABTS. ${ }^{+}$(Table 7). The lowest TPC was determined in the control muffin (6.04 mg GAE/100 g) and the highest in the mealworm and cricket flours (351.05 and $515.76 \mathrm{mg}$ GAE/100 g, respectively). Similar results were obtained by Di Mattia, Battista, Sacchetti, and Serafini [18] for extracts from Acheta domesticus cricket, $299 \mathrm{mg} \mathrm{GAE} / 100 \mathrm{~g}$, and mealworm (T. molitor), $406 \mathrm{mg} \mathrm{GAE} / 100 \mathrm{~g}$. All muffins enriched with insect flour had a higher TPC than the control muffin. Generally, the TPC increased with the higher percentage of insect flour content in muffins. Among muffins with the addition mealworm, the TPC ranged from 6.64 to $34.11 \mathrm{mg} \mathrm{GAE} / 100 \mathrm{~g}$, and for muffins with the addition of 
cricket from 17.53 to $112.06 \mathrm{mg}$ GAE/100 g. The higher TPC in cricket enriched muffins was due to 1.5 times higher TPC in cricket flour than in mealworm flour.

Table 7. Antioxidant properties of muffins.

\begin{tabular}{|c|c|c|c|c|}
\hline $\begin{array}{c}\text { Insect } \\
\text { Species }\end{array}$ & $\begin{array}{l}\text { Insect Flour } \\
\text { Substitution }\end{array}$ & $\begin{array}{c}\text { TPC }(\mathrm{mg} \\
\text { GAE/100 g) }\end{array}$ & $\begin{array}{c}\text { DPPH (mM } \\
\text { TE/100 g) }\end{array}$ & $\begin{array}{c}\text { ABTS (mM } \\
\text { TE/100 g) }\end{array}$ \\
\hline Control & - & $6.04 \pm 0.04 \mathrm{~g}$ & $0.04 \pm 0.008 \mathrm{~g}$ & $0.27 \pm 0.018^{\mathrm{e}}$ \\
\hline $\begin{array}{c}\text { Mealworm } \\
\text { (Tenebrio } \\
\text { molitor) }\end{array}$ & $\begin{array}{c}2 \% \\
6 \% \\
10 \% \\
6 \% \text { of whole insects } \\
\text { insect flour }\end{array}$ & $\begin{array}{c}6.64 \pm 0.1^{\mathrm{g}} \\
25.25 \pm 0.18^{\mathrm{e}} \\
34.11 \pm 0.21^{\mathrm{d}} \\
17.83 \pm 0.15^{\mathrm{f}} \\
351.05 \pm 3.55\end{array}$ & $\begin{array}{c}0.107 \pm 0.02^{\mathrm{f}} \\
0.184 \pm 0.01^{\mathrm{de}} \\
0.223 \pm 0.02^{\mathrm{c}} \\
0.1 \pm 0.004^{\mathrm{f}} \\
1.21 \pm 0.03\end{array}$ & $\begin{array}{c}0.29 \pm 0.023^{\mathrm{de}} \\
0.31 \pm 0.01^{\mathrm{cde}} \\
0.37 \pm 0.03^{\mathrm{c}} \\
0.3 \pm 0.03^{\mathrm{de}} \\
0.93 \pm 0.03\end{array}$ \\
\hline $\begin{array}{c}\text { Cricket } \\
\text { (Gryllodes } \\
\text { sigillatus) }\end{array}$ & $\begin{array}{c}2 \% \\
6 \% \\
10 \% \\
6 \% \text { of whole insects } \\
\text { insect flour }\end{array}$ & $\begin{array}{c}17.53 \pm 0.2^{\mathrm{f}} \\
75.93 \pm 0.52^{\mathrm{b}} \\
112.06 \pm 1.12^{\mathrm{a}} \\
66.73 \pm 0.9^{\mathrm{c}} \\
515.76 \pm 5.2\end{array}$ & $\begin{array}{c}0.159 \pm 0.01^{\mathrm{e}} \\
0.616 \pm 0.01^{\mathrm{b}} \\
0.729 \pm 0.02^{\mathrm{a}} \\
0.192 \pm 0.01^{\mathrm{d}} \\
2.273 \pm 0.12\end{array}$ & $\begin{array}{c}0.35 \pm 0.03^{\mathrm{cd}} \\
0.49 \pm 0.02^{\mathrm{b}} \\
0.59 \pm 0.03^{\mathrm{a}} \\
0.31 \pm 0.01^{\mathrm{cde}} \\
1.15 \pm 0.0\end{array}$ \\
\hline
\end{tabular}

Values with different letters in the same column indicate significant differences $(p<0.05)$.

A similar dependence was observed for the ability to neutralize DPPH and ABTS. ${ }^{+}$. Insect flours showed the strongest antiradical effect, and the cricket flour had a stronger scavenging activity (DPPH. scavenging activity-2.273 mM TE/100 g, and for ABTS.+ ${ }^{+}-1.15 \mathrm{mM}$ TE/100 g) than the mealworm flour (DPPH.scavenging activity $-1.21 \mathrm{mM} \mathrm{TE} / 100 \mathrm{~g}$, and for ABTS $\left.{ }^{+}-0.93 \mathrm{mM} \mathrm{TE} / 100 \mathrm{~g}\right)$. Similarly, Di Mattia et al. [18] reported TEAC values against ABTS. ${ }^{+}$at $2.37 \mathrm{mM} \mathrm{TE} / 100 \mathrm{~g}$ for A. domesticus and $0.89 \mathrm{mM} \mathrm{TE} / 100 \mathrm{~g}$ for T. molitor.

These results correlated with the TPC, where the cricket flour also had the highest TPC of all the samples tested. Moreover, the antioxidant capacity against ABTS. ${ }^{+}$and DPPH. increased correspondingly as the percentage of insect flour in the muffins increased; there is a strong positive correlation between insect flour addition, TCP content, and the ability to neutralize ABTS.+ ${ }^{+}$and DPPH. $(\mathrm{R}=0.970-0.999)$. Similarly, in our previous studies, the antioxidant activity levels of shortcake biscuits increased as the concentration of mealworm flour in the recipe increased [35]. This proves that the bioactive potential of the products is enhanced by the addition of insects.

Both our previous studies [12,25,71], as well as those of other authors [16,18,72], indicated that insects have strong antioxidant properties. The presence of antioxidants in our diet plays an important role in preventing oxidative stress-related diseases, the so-called civilization diseases such as cardiovascular disease or diabetes, as well as the degenerative process associated with aging [12]. Di Mattia et al. [18] noted that in vivo efficiency of foods rich in antioxidants is highly dependent on their bioavailability, which is a very important comment. Additionally, they note that a high antioxidant content in foods is an important requirement for testing the antioxidant potential of novel foods. Therefore, the determination of the in vitro antioxidant potential of insect-enriched products at high levels is a valuable observation for further studies leading to confirmation of this activity in vivo.

\subsection{Rapidly and Slowly Digested Starch Contents and Glycemic Index In Vitro}

Rapidly digestible starch (RDS) is defined as the portion of starch in a product that is digested within $20 \mathrm{~min}$ of food consumption and that causes a rapid rise in blood glucose levels. Slowly digestible starch (SDS) is starch that is completely digested in the small intestine, but at a slower rate than RDS, i.e., within 20-120 min after ingestion, helping to stabilize glucose metabolism [55]. The potential impact of muffins on glycemia could be strong, as evidenced by the significantly higher RDS content than SDS content (Table 8). However, the addition of insect flour to muffins resulted in a reduction of RDS and an 
increase in SDS content $(p<0.05)$. Generally, as the insect flour content in muffins increased, there was a proportional increase in SDS content, with a decrease in RDS content. More significant changes were noted with cricket flour supplementation than mealworm flour. The most significant changes were observed for the 10\% addition of cricket flour; RDS content decreased from $254.17 \mathrm{mg} / \mathrm{g}$ of sample ( $338.04 \mathrm{mg} / \mathrm{g}$ d.w. sample) in the control to $162.18 \mathrm{mg} / \mathrm{g}(221.13 \mathrm{mg} / \mathrm{g}$ d.w. sample), while the SDS content increased from $26.45 \mathrm{mg} / \mathrm{g}$ ( $35.18 \mathrm{mg} / \mathrm{g}$ d.w. sample) in the control to $61.29 \mathrm{mg} / \mathrm{g}$ ( $83.57 \mathrm{mg} / \mathrm{g}$ d.w. sample). Similar results were obtained previously for shortcake biscuits supplemented with mealworm. Samples that contained the highest amounts of mealworm flour had significantly lower contents of RDS and higher contents of SDS than the control [35].

Table 8. Rapidly and slowly digestible starch contents and in vitro glycemic index values for muffins.

\begin{tabular}{|c|c|c|c|c|c|c|}
\hline $\begin{array}{c}\text { Insect } \\
\text { Species }\end{array}$ & $\begin{array}{l}\text { Insect Flour } \\
\text { Substitution }\end{array}$ & $\begin{array}{c}\text { RDS (mg } \\
\text { Glucose/g d.w. } \\
\text { of Sample) }\end{array}$ & $\begin{array}{l}\text { RDS (mg } \\
\text { Glucose/g } \\
\text { Sample) }\end{array}$ & $\begin{array}{c}\text { SDS (mg } \\
\text { Glucose/g d.w. } \\
\text { of Sample) }\end{array}$ & $\begin{array}{l}\text { SDS (mg } \\
\text { Glucose/g } \\
\text { Sample) }\end{array}$ & pGI \\
\hline Control & - & $338.04 \pm 6.47^{\mathrm{ab}}$ & $254.17 \pm 4.86^{\mathrm{a}}$ & $35.18 \pm 1.49^{f}$ & $26.45 \pm 1.12^{f}$ & $92.22 \pm 0.42^{a}$ \\
\hline $\begin{array}{l}\text { Mealworm } \\
\text { (Tenebrio } \\
\text { molitor) }\end{array}$ & $\begin{array}{c}2 \% \\
6 \% \\
10 \% \\
6 \% \text { of whole insects }\end{array}$ & $\begin{array}{l}344.62 \pm 8.07^{a} \\
321.8 \pm 8.75^{b c} \\
321.8 \pm 9.88^{b c} \\
317.7 \pm 5.97^{c d}\end{array}$ & $\begin{array}{c}243.54 \pm 5.7^{\mathrm{ab}} \\
238.58 \pm 6.49^{\mathrm{bc}} \\
227.88 \pm 7.0^{\mathrm{cd}} \\
223.58 \pm 4.2^{\mathrm{cde}}\end{array}$ & $\begin{array}{l}14.63 \pm 1.36^{\mathrm{h}} \\
45.97 \pm 1.55^{\mathrm{e}} \\
78.21 \pm 2.47^{\mathrm{b}} \\
54.51 \pm 2.02^{\mathrm{d}}\end{array}$ & $\begin{array}{l}10.34 \pm 0.96^{\mathrm{h}} \\
32.58 \pm 1.15^{\mathrm{e}} \\
55.43 \pm 1.75^{\mathrm{b}} \\
38.36 \pm 1.42^{\mathrm{d}}\end{array}$ & $\begin{array}{r}90.55 \pm 0.38^{\mathrm{ab}} \\
84.50 \pm 0.44^{\mathrm{c}} \\
81.16 \pm 0.52^{\mathrm{de}} \\
83.73 \pm 0.36^{\mathrm{cd}}\end{array}$ \\
\hline $\begin{array}{c}\text { Cricket } \\
\text { (Gryllodes } \\
\text { sigillatus) }\end{array}$ & $\begin{array}{c}2 \% \\
6 \% \\
10 \% \\
6 \% \text { of whole insects }\end{array}$ & $\begin{array}{l}312.7 \pm 6.06^{\mathrm{cd}} \\
300.51 \pm 5.34^{\mathrm{d}} \\
221.13 \pm 4.77^{\mathrm{f}} \\
249.21 \pm 5.02^{\mathrm{e}}\end{array}$ & $\begin{array}{c}212.51 \pm 4.12^{\mathrm{e}} \\
219.10 \pm 3.89^{\mathrm{de}} \\
162.18 \pm 3.5^{\mathrm{g}} \\
181.30 \pm 3.65^{\mathrm{f}}\end{array}$ & $\begin{array}{c}25.87 \pm 0.79^{g} \\
63.3 \pm 2.54^{\mathrm{c}} \\
83.57 \pm 1.64^{\mathrm{a}} \\
60.01 \pm 2.12^{\mathrm{c}}\end{array}$ & $\begin{array}{c}17.58 \pm 0.54^{\mathrm{g}} \\
46.21 \pm 1.85^{\mathrm{c}} \\
61.29 \pm 1.2^{\mathrm{a}} \\
43.66 \pm 1.54^{\mathrm{c}}\end{array}$ & $\begin{array}{l}88.78 \pm 0.42^{b} \\
85.71 \pm 0.44^{c} \\
79.30 \pm 0.39^{e} \\
80.74 \pm 0.48^{e}\end{array}$ \\
\hline
\end{tabular}

Values with different letters in the same column indicate significant differences $(p<0.05)$.

Muffins baked with rice, wheat, oat, corn, and barley flour showed similar SDS contents, but with a much higher RDS content, in the range of 387 to $445 \mathrm{mg}$ glucose/g muffin [56]. The digestibility of starch present in foods, especially those subjected to different types of heat treatment, is dependent on other components present in the food. These other components may include proteins, and interactions between them are crucial modifications to starch digestibility [73]. In line with these reports, insect proteins may interact with starch, resulting in higher SDS content.

Moreover, we determined that an increase in the addition of cricket flour caused a decrease in RDS content, but in the case of mealworm the decrease in RDS content was observed only up to a certain point, of $6 \%$, and further addition of flour did not affect the RDS content. The reason for this phenomenon may be the lower protein content of mealworms $(54.29 \%)$ than crickets $(71.15 \%)$ and the need for an even higher addition of flour to record successive decreases in RDS. Another reason may be the type and manner of interactions occurring between the starch and the components contained in the insects; the protein [74], fiber [75], fat [76], and phenolic compounds [77]. Furthermore, the addition of whole crickets caused a higher decrease in RDS than the addition of the same amount of cricket flour, which is probably related to the presence of these macronutrients in a different form. Non-starchy ingredients contained in food affect starch digestibility by forming ordered starch structures and/or reducing enzyme activity [78]. In general, starch interacted with lipids or proteins through electrostatic and hydrophobic interactions and this increased the ordered structures of starch to slow down the starch digestibility. These interactions play a key role in modulating digestibility and may occur under different conditions [79]. Protein affects the functional properties of starch, such as the rate of gelatinization and digestion of starch, because protein can form a continuous layer surrounding the starch granules $[80,81]$. Lipids also limit the availability and binding of enzymes to starch molecules. Lipids existing outside the starch granule can form complexes with amylose after heat treatment, limiting the swelling and solubility of starch granules [82]. Fiber is also one of the factors involved in starch digestion. The inclusion of soluble fibers 
increases the resistance of starch to enzymatic degradation because it can result in the formation of a viscous protein-fiber-starch network that can trap starch granules, limiting the release of glucose [75]. An example is the effect of guar gum in lowering postprandial glycemia and insulinemia by influencing intestinal physiology, and directly inhibiting the first step of biochemical starch degradation, i.e., amylolysis [83]. This action can occur in two ways: by altering the viscosity of the food matrix, affecting the rate of starch digestion; and can also play the role of a physical barrier, reducing enzyme-substrate interactions [84]. Therefore, the addition of insect meal as a source of ingredients that interact with starch promotes a reduction in starch digestibility through the complex transformations and reactions that occur during the heat treatment of muffins. Changes in starch digestibility can be manifested by both a decrease in RDS and an increase in SDS, as well as a lack in the availability of digestive enzymes to starch at the tested digestion time of $120 \mathrm{~min}$. Foods containing carbohydrates can be classified according to their potential effect on postprandial blood glucose levels ('glycaemic response'), which can be assessed as the glycaemic index (GI) [85]. The predicted glycemic index (pGI) was lower for the fortified muffins than the control $(p<0.05)$ (Table 8). A lower predicted glycemic index was observed for muffins with the highest SDS content; muffins with the addition of $10 \%$ of cricket flour, $6 \%$ of whole insects, and $10 \%$ of mealworm flour (pGI 79.3, 80.74, and 81.16, respectively), whereas the pGI of the control muffin was calculated as 92.22 . These results suggest important low-glycemic characteristics of insect flours. Modulating the postprandial blood glucose response (by consuming foods with a low GI) has positive health effects, therefore further research is warranted in this area. Attempts are made to lower the glycemic index of products by adding various ingredients to the base recipe. Examples would be resistant starch, dextrins, or lentil flour, which decreased the pGI of muffins by 3.6 [86].

\section{Conclusions}

Edible insects can be incorporated into bakery products to improve their nutritional value, mainly in terms of protein content. The proposed food matrix was muffins, but this is just one example of presenting insects in a way that is attractive to the consumer. Based on the consumer evaluation, we can conclude that the addition of insects in the form of flour is a better ingredient than the addition of whole insects, as this provided a higher consumer acceptance.

The fortification of muffins with insect flours also affected their physical characteristics. Increasing the amount of insect flour decreased the lightness $\left(\mathrm{L}^{*}\right)$, while increasing the total color difference $(\Delta \mathrm{E})$. The supplementation of muffins with insect flour gave the muffins a softer texture compared to the control, as evidenced by the significant $(p<0.05)$ decrease in hardness, springiness, resilience, cohesiveness, and chewiness of the muffins.

In addition to studying the effect of insect flour addition on the physicochemical properties of muffins, the effect of their fortification on the potential biological activity of the products was also investigated. The antioxidant capacity against ABTS. ${ }^{+}$and DPPH., as well as total phenolic content (TPC), increased correspondingly as the percentage of insect flour in the muffins increased. The addition of insect flour to muffins resulted in a reduction of rapidly digested starch (RDS) and an increase in slowly digested starch (SDS) content $(p<0.05)$. Furthermore, this fortification resulted in a lower predicted glycemic index. This is important information because of the great interest in lower glycemic index products by people who often struggle with various conditions such as obesity, diabetes, and insulin resistance. Confirmation of the ability of insects to lower the glycemic index in vivo would allow them to be used to produce foods of this nature.

The results of these analyses indicate that there are many positive benefits to using insects in traditional foods. This encourages further research, in which it would be valuable to use other food matrices and extend the evaluation to a complete sensory analysis of the obtained products, which is a necessary step for marketing this type of product in Western countries. 
Author Contributions: Conceptualization, E.Z., U.P. and M.S.; Methodology, E.Z. and M.S.; Investigation, E.Z.; Data Curation, E.Z.; Writing-Original Draft Preparation, E.Z.; Writing-Review \& Editing, U.P. and M.S.; Supervision, U.P. All authors have read and agreed to the published version of the manuscript.

Funding: This research received no external funding.

Institutional Review Board Statement: Not applicable.

Informed Consent Statement: Not applicable.

Data Availability Statement: The data presented in this study are available on request from the corresponding author. The data are not publicly available due to their large amount.

Conflicts of Interest: The authors declare no conflict of interest.

\section{References}

1. Agrahar-Murugkar, D. Food to food fortification of breads and biscuits with herbs, spices, millets and oilseeds on bio-accessibility of calcium, iron and zinc and impact of proteins, fat and phenolics. LWT 2020, 130, 109703. [CrossRef]

2. Cappelli, A.; Oliva, N.; Bonaccorsi, G.; Lorini, C.; Cini, E. Assessment of the rheological properties and bread characteristics obtained by innovative protein sources (Cicer arietinum, Acheta domesticus, Tenebrio molitor): Novel food or potential improvers for wheat flour? LWT 2020, 118, 108867. [CrossRef]

3. González, C.M.; Garzón, R.; Rosell, C.M. Insects as ingredients for bakery goods. A comparison study of H. illucens, A. domestica and T. molitor flours. Innov. Food Sci. Emerg. Technol. 2019, 51, 205-210. [CrossRef]

4. Payne, C.L.R.; Scarborough, P.; Rayner, M.; Nonaka, K. A systematic review of nutrient composition data available for twelve commercially available edible insects, and comparison with reference values. Trends Food Sci. Technol. 2016, 47, 69-77. [CrossRef]

5. Montowska, M.; Kowalczewski, P.Ł.; Rybicka, I.; Fornal, E. Nutritional value, protein and peptide composition of edible cricket powders. Food Chem. 2019, 289, 130-138. [CrossRef]

6. Nongonierma, A.B.; FitzGerald, R.J. Unlocking the biological potential of proteins from edible insects through enzymatic hydrolysis: A review. Innov. Food Sci. Emerg. Technol. 2017, 43, 239-252. [CrossRef]

7. Seabrooks, L.; Hu, L. Insects: An underrepresented resource for the discovery of biologically active natural products. Acta Pharm. Sin. B 2017, 7, 409-426. [CrossRef]

8. Ushakova, N.A.; Brodsky, E.S.; Tikhonova, O.V.; Dontsov, A.E.; Marsova, M.V.; Shelepchikov, A.A.; Bastrakov, A.I. Novel Extract from Beetle Ulomoides dermestoides: A Study of Composition and Antioxidant Activity. Antioxidants 2021, 10, 1055. [CrossRef] [PubMed]

9. Santos, R.C.V.; Lunardelli, A.; Caberlon, E.; Bastos, C.M.A.; Nunes, F.B.; Pires, M.G.S.; Biolchi, V.; Paul, E.L.; Vieira, F.B.C.; Do Carmo Aquino, A.R.; et al. Anti-inflammatory and immunomodulatory effects of Ulomoides dermestoides on induced pleurisy in rats and lymphoproliferation in vitro. Inflammation 2010, 33, 173-179. [CrossRef] [PubMed]

10. Stull, V.J.; Finer, E.; Bergmans, R.S.; Febvre, H.P.; Longhurst, C.; Manter, D.K.; Patz, J.A.; Weir, T.L. Impact of Edible Cricket Consumption on Gut Microbiota in Healthy Adults, a Double-blind, Randomized Crossover Trial. Sci. Rep. 2018, 8, 1-13. [CrossRef]

11. Dutta, P.; Dey, T.; Dihingia, A.; Manna, P.; Kalita, J. Antioxidant and glucose metabolizing potential of edible insect, Brachytrupes orientalis via modulating Nrf2/AMPK/GLUT4 signaling pathway. Biomed. Pharmacother. 2017, 95, 556-563. [CrossRef] [PubMed]

12. Zielińska, E.; Baraniak, B.; Karaś, M. Antioxidant and anti-inflammatory activities of hydrolysates and peptide fractions obtained by enzymatic hydrolysis of selected heat-treated edible insects. Nutrients 2017, 9, 970. [CrossRef]

13. Zielińska, E.; Baraniak, B.; Karaś, M. Identification of antioxidant and anti-inflammatory peptides obtained by simulated gastrointestinal digestion of three edible insects species (Gryllodes sigillatus, Tenebrio molitor, Schistocerca gragaria). Int. J. Food Sci. Technol. 2018, 53, 2542-2551. [CrossRef]

14. Zielińska, E.; Karaś, M.; Baraniak, B.; Jakubczyk, A. Evaluation of ACE, $\alpha$-glucosidase, and lipase inhibitory activities of peptides obtained by in vitro digestion of selected species of edible insects. Eur. Food Res. Technol. 2020, 1-9. [CrossRef]

15. Botella-Martínez, C.; Lucas-González, R.; Pérez-Álvarez, J.A.; Fernández-López, J.; Viuda-Martos, M. Assessment of chemical composition and antioxidant properties of defatted flours obtained from several edible insects. Food Sci. Technol. Int. 2021, $27,383-391$. [CrossRef] [PubMed]

16. Mintah, B.K.; He, R.; Dabbour, M.; Xiang, J.; Agyekum, A.A.; Ma, H. Techno-functional attribute and antioxidative capacity of edible insect protein preparations and hydrolysates thereof: Effect of multiple mode sonochemical action. Ultrason. Sonochem. 2019, 58, 104676. [CrossRef]

17. Cömert, E.D.; Gökmen, V. Evolution of food antioxidants as a core topic of food science for a century. Food Res. Int. 2018, 105, 76-93. [CrossRef]

18. Di Mattia, C.; Battista, N.; Sacchetti, G.; Serafini, M. Antioxidant activities in vitro of water and liposoluble extracts obtained by different species of edible insects and invertebrates. Front. Nutr. 2019, 6. [CrossRef]

19. Świeca, M. Designing the antioxidant properties of low-processed food. Antioxidants 2020, 9, 975. [CrossRef] 
20. Carocho, M.; Morales, P.; Ferreira, I.C.F.R. Antioxidants: Reviewing the chemistry, food applications, legislation and role as preservatives. Trends Food Sci. Technol. 2018, 71, 107-120. [CrossRef]

21. Van Broekhoven, S.; Oonincx, D.G.A.B.; van Huis, A.; van Loon, J.J.A. Growth performance and feed conversion efficiency of three edible mealworm species (Coleoptera: Tenebrionidae) on diets composed of organic by-products. J. Insect Physiol. 2015, 73, 1-10. [CrossRef]

22. Oonincx, D.G.A.B.; Van Broekhoven, S.; Van Huis, A.; Van Loon, J.J.A. Feed conversion, survival and development, and composition of four insect species on diets composed of food by-products. PLoS ONE 2015, 10, e144601. [CrossRef] [PubMed]

23. Oonincx, D.G.A.B.; van Itterbeeck, J.; Heetkamp, M.J.W.; van den Brand, H.; van Loon, J.J.A.; van Huis, A. An exploration on greenhouse gas and ammonia production by insect species suitable for animal or human consumption. PLoS ONE 2010, 5, e14445 [CrossRef] [PubMed]

24. Oonincx, D.G.A.B.; de Boer, I.J.M. Environmental Impact of the Production of Mealworms as a Protein Source for Humans-A Life Cycle Assessment. PLoS ONE 2012, 7, e51145. [CrossRef] [PubMed]

25. Zielińska, E.; Zieliński, D.; Karaś, M.; Jakubczyk, A. Exploration of consumer acceptance of insects as food in Poland. J. Insects Food Feed 2020, 6, 383-392. [CrossRef]

26. Roma, R.; Ottomano Palmisano, G.; De Boni, A. Insects as Novel Food: A Consumer Attitude Analysis through the DominanceBased Rough Set Approach. Foods 2020, 9, 387. [CrossRef] [PubMed]

27. La Barbera, F.; Verneau, F.; Videbæk, P.N.; Amato, M.; Grunert, K.G. A self-report measure of attitudes toward the eating of insects: Construction and validation of the Entomophagy Attitude Questionnaire. Food Qual. Prefer. 2020, 79, 103757. [CrossRef]

28. Hartmann, C.; Shi, J.; Giusto, A.; Siegrist, M. The psychology of eating insects: A cross-cultural comparison between Germany and China. Food Qual. Prefer. 2015, 44, 148-156. [CrossRef]

29. Tan, H.S.G.; van den Berg, E.; Stieger, M. The influence of product preparation, familiarity and individual traits on the consumer acceptance of insects as food. Food Qual. Prefer. 2016, 52, 222-231. [CrossRef]

30. Delicato, C.; Schouteten, J.J.; Dewettinck, K.; Gellynck, X.; Tzompa-Sosa, D.A. Consumers' perception of bakery products with insect fat as partial butter replacement. Food Qual. Prefer. 2020, 79, 103755. [CrossRef]

31. Haber, M.; Mishyna, M.; Martinez, J.J.I.; Benjamin, O. The influence of grasshopper (Schistocerca gregaria) powder enrichment on bread nutritional and sensorial properties. LWT 2019, 115, 108395. [CrossRef]

32. Kowalczewski, P.Ł.; Walkowiak, K.; Masewicz, Ł.; Bartczak, O.; Lewandowicz, J.; Kubiak, P.; Baranowska, H.M. Gluten-free bread with cricket powder-Mechanical properties and molecular water dynamics in dough and ready product. Foods 2019, 8, 240. [CrossRef] [PubMed]

33. Kowalczewski, P.Ł.; Gumienna, M.; Rybicka, I.; Górna, B.; Sarbak, P.; Dziedzic, K.; Kmiecik, D. Nutritional Value and Biological Activity of Gluten-Free Bread Enriched with Cricket Powder. Molecules 2021, 26, 1184. [CrossRef] [PubMed]

34. Ayensu, J.; Lutterodt, H.; Annan, R.A.; Edusei, A.; Loh, S.P. Nutritional composition and acceptability of biscuits fortified with palm weevil larvae (Rhynchophorus phoenicis Fabricius) and orange-fleshed sweet potato among pregnant women. Food Sci. Nutr. 2019, 7, 1807-1815. [CrossRef] [PubMed]

35. Zielińska, E.; Pankiewicz, U. Nutritional, Physiochemical, and Antioxidative Characteristics of Shortcake Biscuits Enriched with Tenebrio molitor Flour. Molecules 2020, 25, 5629. [CrossRef] [PubMed]

36. Homann, A.M.; Ayieko, M.A.; Konyole, S.O.; Roos, N. Acceptability of biscuits containing 10\% cricket (Acheta domesticus) compared to milk biscuits among 5-10-year-old Kenyan schoolchildren. J. Insects as Food Feed 2017, 3, 95-103. [CrossRef]

37. Adámek, M.; Adámková, A.; Mlček, J.; Borkovcová, M.; Bednářová, M. Acceptability and sensory evaluation of energy bars and protein bars enriched with edible insect. Potravin. Slovak J. Food Sci. 2018, 12, 431-437. [CrossRef]

38. Severini, C.; Azzollini, D.; Albenzio, M.; Derossi, A. On printability, quality and nutritional properties of 3D printed cereal based snacks enriched with edible insects. Food Res. Int. 2018, 106, 666-676. [CrossRef]

39. Duda, A.; Adamczak, J.; Chelminska, P.; Juszkiewicz, J.; Kowalczewski, P. Quality and nutritional/textural properties of durum wheat pasta enriched with cricket powder. Foods 2019, 8, 46. [CrossRef]

40. Aguilar-Miranda, E.D.; López, M.G.; López, L.; Escamilla-Santana, C.; Barba De, A.P.; Rosa, L.A. Characteristics of Maize Flour Tortilla Supplemented with Ground Tenebrio molitor Larvae. J Agric. Food Chem. 2002. [CrossRef]

41. De Smet, J.; Lenaerts, S.; Borremans, A.; Scholliers, J.; Van Der Borght, M.; Van Campenhout, L. Stability assessment and laboratory scale fermentation of pastes produced on a pilot scale from mealworms (Tenebrio molitor). LWT 2019, 102, 113-121. [CrossRef]

42. Smarzyński, K.; Sarbak, P.; Musiał, S.; Jezowski, P.; Piatek, M.; Kowalczewski, P.T. Nutritional analysis and evaluation of the consumer acceptance of pork pâté enriched with cricket powder-preliminary study. Open Agric. 2019, 4, 159-163. [CrossRef]

43. Choi, Y.S.; Kim, T.K.; Choi, H.D.; Park, J.D.; Sung, J.M.; Jeon, K.H.; Paik, H.D.; Kim, Y.B. Optimization of replacing pork meat with yellow worm (Tenebrio molitor L.) for frankfurters. Korean J. Food Sci. Anim. Resour. 2017, 37, 617-625. [CrossRef] [PubMed]

44. Kim, H.W.; Setyabrata, D.; Lee, Y.J.; Jones, O.G.; Kim, Y.H.B. Pre-treated mealworm larvae and silkworm pupae as a novel protein ingredient in emulsion sausages. Innov. Food Sci. Emerg. Technol. 2016, 38, 116-123. [CrossRef]

45. Schouteten, J.J.; De Steur, H.; De Pelsmaeker, S.; Lagast, S.; Juvinal, J.G.; De Bourdeaudhuij, I.; Verbeke, W.; Gellynck, X. Emotional and sensory profiling of insect-, plant- and meat-based burgers under blind, expected and informed conditions. Food Qual. Prefer. 2016, 52, 27-31. [CrossRef]

46. Kusch, S.; Fiebelkorn, F. Environmental impact judgments of meat, vegetarian, and insect burgers: Unifying the negative footprint illusion and quantity insensitivity. Food Qual. Prefer. 2019, 78, 103731. [CrossRef] 
47. AOAC. Official Methods of Analysis; AOAC International: Rockville, MD, USA, 2010; pp. 2-4.

48. European Parliament. Regulation (EU) No 1169/2011 of the European Parliament and of the Council of 25 October 2011 on the provision of food information to consumers. Off. J. Eur. Union 2011, 304, $18-63$.

49. Mildner-Szkudlarz, S.; Bajerska, J.; Górnaś, P.; Seglina, D.; Pilarska, A.; Jesionowski, T. Physical and Bioactive Properties of Muffins Enriched with Raspberry and Cranberry Pomace Powder: A Promising Application of Fruit By-Products Rich in Biocompounds. Plant. Foods Hum. Nutr. 2016. [CrossRef]

50. Mazzocchi, M. Statistics for Marketing and Consumer Research; Sage: London, UK, 2008.

51. Antoniewska, A.; Rutkowska, J.; Pineda, M.M.; Adamska, A. Antioxidative, nutritional and sensory properties of muffins with buckwheat flakes and amaranth flour blend partially substituting for wheat flour. LWT Food Sci. Technol. 2018, 89, 217-223. [CrossRef]

52. Brand-Williams, W.; Cuvelier, M.E.; Berset, C. Use of a free radical method to evaluate antioxidant activity. LWT Food Sci. Technol. 1995, 28, 25-30. [CrossRef]

53. Re, R.; Pellegrini, N.; Proteggente, A.; Pannala, A.; Yang, M.; Rice-Evans, C. Antioxidant activity applying an improved ABTS radical cation decolorization assay. Free Radic. Biol. Med. 1999, 26, 1231-1237. [CrossRef]

54. Singleton, V.L.; Rossi, J.A. Colorimetry of Total Phenolics with Phosphomolybdic-Phosphotungstic Acid Reagents. Am. J. Enol. Vitic. 1965, 16, 144-158.

55. Monro, J.A.; Wallace, A.; Mishra, S.; Eady, S.; Willis, J.A.; Scott, R.S.; Hedderley, D. Relative glycaemic impact of customarily consumed portions of eighty-three foods measured by digesting in vitro and adjusting for food mass and apparent glucose disposal. Br. J. Nutr. 2010, 104, 407-417. [CrossRef] [PubMed]

56. Soong, Y.Y.; Tan, S.P.; Leong, L.P.; Henry, J.K. Total antioxidant capacity and starch digestibility of muffins baked with rice, wheat, oat, corn and barley flour. Food Chem. 2014, 164, 462-469. [CrossRef] [PubMed]

57. Reis, S.F.; Abu-Ghannam, N. Antioxidant capacity, arabinoxylans content and invitro glycaemic index of cereal-based snacks incorporated with brewer's spent grain. LWT Food Sci. Technol. 2014, 55, 269-277. [CrossRef]

58. Goñi, I.; Garcia-Alonso, A.; Saura-Calixto, F. A starch hydrolysis procedure to estimate glycemic index. Nutr. Res. 1997, 17, 427-437. [CrossRef]

59. Zielińska, E.; Karaś, M.; Baraniak, B. Comparison of functional properties of edible insects and protein preparations thereof. LWT Food Sci. Technol. 2018, 91, 168-174. [CrossRef]

60. Pauter, P.; Różańska, M.; Wiza, P.; Dworczak, S.; Grobelna, N.; Sarbak, P.; Kowalczewski, P. Effects of the replacement of wheat flour with cricket powder on the characteristics of muffins. Acta Sci. Pol. Technol. Aliment. 2018, 17, 227-233. [CrossRef]

61. Sozer, N.; Cicerelli, L.; Heiniö, R.L.; Poutanen, K. Effect of wheat bran addition on invitro starch digestibility, physico-mechanical and sensory properties of biscuits. J. Cereal Sci. 2014, 60, 105-113. [CrossRef]

62. Laguna, L.; Salvador, A.; Sanz, T.; Fiszman, S.M. Performance of a resistant starch rich ingredient in the baking and eating quality of short-dough biscuits. LWT Food Sci. Technol. 2011, 44, 737-746. [CrossRef]

63. Kaur, A.; Virdi, A.S.; Singh, N.; Singh, A.; Kaler, R.S.S. Effect of degree of milling and defatting on proximate composition, functional and texture characteristics of gluten-free muffin of bran of long-grain indica rice cultivars. Food Chem. 2021, 345, 128861. [CrossRef]

64. Kaur, R.; Kaur, M. Microstructural, physicochemical, antioxidant, textural and quality characteristics of wheat muffins as influenced by partial replacement with ground flaxseed. LWT Food Sci. Technol. 2018, 91, 278-285. [CrossRef]

65. Srivastava, D.; Rajiv, J.; Mahadevamma; Naidu, M.M.; Puranaik, J.; Srinivas, P. Effect of Fenugreek Seed Husk on the Rheology and Quality Characteristics of Muffins. Food Nutr. Sci. 2012, 3, 1473-1479. [CrossRef]

66. Goswami, D.; Gupta, R.K.; Mridula, D.; Sharma, M.; Tyagi, S.K. Barnyard millet based muffins: Physical, textural and sensory properties. LWT Food Sci. Technol. 2015, 64, 374-380. [CrossRef]

67. Dziki, D.; Siastala, M.; Laskowski, J. Ocena właściwości fizycznych pieczywa handlowego. Acta Agrophys. 2011, 18, $235-244$.

68. Orsi, L.; Voege, L.L.; Stranieri, S. Eating edible insects as sustainable food? Exploring the determinants of consumer acceptance in Germany. Food Res. Int. 2019, 125, 108573. [CrossRef]

69. De Boer, J.; Schösler, H.; Boersema, J.J. Motivational differences in food orientation and the choice of snacks made from lentils, locusts, seaweed or "hybrid" meat. Food Qual. Prefer. 2013, 28, 32-35. [CrossRef]

70. Barton, A.; Richardson, C.D.; McSweeney, M.B. Consumer attitudes toward entomophagy before and after evaluating cricket (Acheta domesticus)-based protein powders. J. Food Sci. 2020, 85, 781-788. [CrossRef]

71. Zielińska, E.; Karaś, M.; Jakubczyk, A. Antioxidant activity of predigested protein obtained from a range of farmed edible insects. Int. J. Food Sci. Technol. 2017, 52, 306-312. [CrossRef]

72. Navarro del Hierro, J.; Gutiérrez-Docio, A.; Otero, P.; Reglero, G.; Martin, D. Characterization, antioxidant activity, and inhibitory effect on pancreatic lipase of extracts from the edible insects Acheta domesticus and Tenebrio molitor. Food Chem. 2020, $309,125742$. [CrossRef]

73. Jenkins, D.J.; Kendall, C.W.; Augustin, L.S.; Franceschi, S.; Hamidi, M.; Marchie, A.; Jenkins, A.L.; Axelsen, M. Glycemic index: Overview of implications in health and disease. Am. J. Clin. Nutr. 2002, 76, 266S-273S. [CrossRef] [PubMed]

74. Chi, C.; Li, X.; Zhang, Y.; Chen, L.; Li, L. Understanding the mechanism of starch digestion mitigation by rice protein and its enzymatic hydrolysates. Food Hydrocoll. 2018, 84, 473-480. [CrossRef] 
75. Rakhesh, N.; Fellows, C.M.; Sissons, M. Evaluation of the technological and sensory properties of durum wheat spaghetti enriched with different dietary fibres. J. Sci. Food Agric. 2015, 95, 2-11. [CrossRef]

76. Chi, C.; Li, X.; Feng, T.; Zeng, X.; Chen, L.; Li, L. Improvement in Nutritional Attributes of Rice Starch with Dodecyl Gallate Complexation: A Molecular Dynamic Simulation and In Vitro Study. J. Agric. Food Chem. 2018, 66. [CrossRef]

77. Chi, C.; Li, X.; Zhang, Y.; Chen, L.; Xie, F.; Li, L.; Bai, G. Modulating the in vitro digestibility and predicted glycemic index of rice starch gels by complexation with gallic acid. Food Hydrocoll. 2019, 89, 821-828. [CrossRef]

78. Lin, L.; Yang, H.; Chi, C.; Ma, X. Effect of protein types on structure and digestibility of starch-protein-lipids complexes. LWT 2020, 134, 110175. [CrossRef]

79. Chao, C.; Yu, J.; Wang, S.; Copeland, L.; Wang, S. Mechanisms Underlying the Formation of Complexes between Maize Starch and Lipids. J. Agric. Food Chem. 2018, 66, 272-278. [CrossRef] [PubMed]

80. Ezeogu, L.I.; Duodu, K.G.; Taylor, J.R.N. Effects of endosperm texture and cooking conditions on the in vitro starch digestibility of sorghum and maize flours. J. Cereal Sci. 2005, 42, 33-44. [CrossRef]

81. Ezeogu, L.I.; Duodu, K.G.; Emmambux, M.N.; Taylor, J.R.N. Influence of cooking conditions on the protein matrix of sorghum and maize endosperm flours. Cereal Chem. 2008, 85, 397-402. [CrossRef]

82. Björck, I.; Granfeldt, Y.; Liljeberg, H.; Tovar, J.; Asp, N.G. Food properties affecting the digestion and absorption of carbohydrates. Am. J. Clin. Nutr. 1994, 59. [CrossRef]

83. Slaughter, S.L.; Ellis, P.R.; Jackson, E.C.; Butterworth, P.J. The effect of guar galactomannan and water availability during hydrothermal processing on the hydrolysis of starch catalysed by pancreatic $\alpha$-amylase. Biochim. Biophys. Acta Gen. Subj. 2002, 1571, 55-63. [CrossRef]

84. Hardacre, A.K.; Yap, S.Y.; Lentle, R.G.; Monro, J.A. The effect of fibre and gelatinised starch type on amylolysis and apparent viscosity during in vitro digestion at a physiological shear rate. Carbohydr. Polym. 2015, 123, 80-88. [CrossRef] [PubMed]

85. Sanchez-Rivera, M.M.; Bello-Pérez, L.A.; Tovar, J.; Martinez, M.M.; Agama-Acevedo, E. Esterified plantain flour for the production of cookies rich in indigestible carbohydrates. Food Chem. 2019, 292, 1-5. [CrossRef] [PubMed]

86. Ferrer-Mairal, A.; Peñalva-Lapuente, C.; Iglesia, I.; Urtasun, L.; De Miguel-Etayo, P.; Remón, S.; Cortés, E.; Moreno, L.A. In vitro and in vivo assessment of the glycemic index of bakery products: Influence of the reformulation of ingredients. Eur. J. Nutr. 2012, 51, 947-954. [CrossRef] 